\title{
PENINGKATAN KETERAMPILAN MOTORIK HALUS ANAK DENGAN KEGIATAN KOLASE BAHAN DAUN KERING DI KELOMPOK B TK PUSAKA INDAH SAMARINDA TAHUN AJARAN 2017-2018
}

\author{
Sariyem \\ PG PAUD Universitas Widya Gama Mahakam Samarinda \\ Sariyem.551@gmail.com \\ Mahkamah Brantasari \\ PG PAUD Universitas Widya Gama Mahakam Samarinda \\ brantasari@gmail.com \\ Harry Gunawan \\ PG PAUD Universitas Widya Gama Mahakam Samarinda \\ Harrygunawan2377@gmail.com
}

\begin{abstract}
Abstrak
Students in Pustaka Indah Kindergarten Samarinda were considered having low sensory motor skill due to lack of physical practic, unattactive facilities of learning, less maximum guide frorm the teacher, and less various teaching method. Responding the issue, the researcher applied a classroom action research to improve student' motor skill through collage activity by using dried leaves. This study involved 20 students of Group B at Pustaka Indah Kindergarten as the research subject. Moreover, observation sheets and documentation of learning activity were employed to collect the data. The data was then analyzed through descriptive quantitative and qualitatively. The research was carried out in three cycles, wherein each cycle consists of four stages; planning, implementation, observation and reflection. Having analyed the data, students' sensory motor skill increased after implementing the collage activity. Based on observation sheet on the students' average score in pre cycle, $0 \%$ students did not reach the passing grade. However, at the first cycle, $40 \%$ students managed to improve their sensory motor skill, which then increased in the second cycle, making up 70,33\% with good category. In conclusion, the collage activity has effectively improved students' sensory motor skill, especially for students in Pusaka Indah Kindergarten Samarinda.
\end{abstract}

Key words : sensory motor skill, collage, dried leaves

\section{PENDAHULUAN}

Pendidikan anak usia dini adalah suatu upaya pembinaan yang ditujukan kepada anak sejak lahir sampai dengan usia enam tahun yang dilakukan melalui pemberian rangsangan pendidikan untuk membantu pertumbuhan dan perkembangan jasmani dan rohani agar anak memiliki kesiapan dalam memasuki pendidikan lebih lanjut, seperti yang tercantum dalam Undang-Undang Nasional Tahun 2003 Pasal 7 yang berbunyi "Orang tua berhak berperan serta dalam memilih satuan pendidikan dan memperoleh informasi tentang perkembangan pendidikan anaknya".

Anak usia dini memiliki karakteristik yang khas, baik secara fisik, 
psikis, sosial, moral, dan sebagainya. Masa kanak-kanak juga masa yang paling penting untuk sepanjang usia hidupnya, sebab masa kanak-kanak adalah masa pembentukan fondasi dan dasar kepribadian yang akan menentukan pengalaman anak selanjutnya. Pengalaman yang dialami anak pada usia dini akan berpengaruh kuat terhadap kehidupannya. Pengalaman tersebut akan bertahan lama, bahkan tidak dapat terhapuskan.

Beberapa hal menjadi alasan pentingnya memahami karakteristik anak usia dini antara lain karena usia dini merupakan usia yang paling penting dalam tahap perkembangan manusia, sebab usia tersebut merupakan periode diletakannya dasar kepribadian yang dibangun untuk sepanjang hidupnya.

Dalam Undang-undang Nomor 20 Tahun 2003 tentang Sistem Pendidikan Nasional, pasal 28 menyebutkan bahwa Taman Kanak-kanak (TK) merupakan bentuk pendidikan anak usia dini jalur formal yang menyelenggarakan pendidikan bagi anak usia empat tahun sampai enam tahun yang diselenggarakan sebelum memasuki jenjang pendidikan dasar. Taman Kanak-kanak (TK) adalah jenjang pendidikan anak usia dini (yakni usia 6 tahun atau di bawahnya) dalam bentuk pendidikan formal. Kurikulum TK ditekankan pada pemberian rangsangan pendidikan untuk membantu pertumbuhan dan perkembangan jasmani dan rohani agar anak memiliki kesiapan dalam memasuki pendidikan lebih lanjut.oleh karena itu pendidikan anak usia dini ditekankan pada pendidikan karakter sehingga bakat, minat dan kemampuan anak dapat tersalurakan dengan baik.

Pembelajaran di TK adalah dengan memberi kesempatan belajar dan kurikulum pembelajaran yang sesuai dengan usia tiap tingkatannya. Anak diajarkan mengenai kemampuan agama, budi bahasa, berhitung, membaca (lebih tepatnya mengenal aksara dan ejaan), bernyanyi, bersosialisasi dalam lingkungan keluarga dan teman-teman sepermainannya, dan berbagai macam keterampilan lainnya. Tujuannya yaitu meningkatkan daya cipta kanak-kanak dan memacunya untuk belajar mengenal bermacam-macam ilmu pengetahuan melalui pendekatan nilai budi bahasa, agama, sosial, emosional, fisik/motorik, kognitif, bahasa, seni, dan kemandirian. Semua dirancang sebagai upaya menumbuhkembangkan daya pikir dan peranan anak kecil dalam kehidupannya. Semua kegiatan belajar ini dikemas dalam model belajar sambil bermain. Pada hakikatnya setiap manusia diciptakan oleh Tuhan sebagai mahkluk yang istimewa karena manusa memiliki akal dan pikiran. Kedua hal inilah yang membedakan manusia dari makhluk ciptaan Tuhan yang lainnya seperti hewan atau tumbuhan. Melalui akal dan pikiran yang ada didalam diri manusia sudah seharusnya manusia 
Jurnal Warna : Jurnal Pendidikan Dan Pembelajaran Anak Usia dini. September 2018. Vol 03. No. 02

dapat bertingkah laku sesuai dengan kodratnya sebagai individu manusia. Untuk dapat menggunakan akal pikirannya tersebut, manusia memerlukan kemampuan , tidak terkecuali pada seorang anak.

Ketrampilan kolase adalah merupakan kemampuan seseorang dalam menempelkan benda yang berupa pecahan kulit telur atau potongan kertas pada bidang gambar yang menghasilkan sebuah karya seni yang menarik, membuat kolase dibutuhkan koordinasi mata dan tangan serta konsentrasi sehingga kolase cocok untuk melatih anak dalam meningkatkan kemampuan motorik halus dan melatih kesabaran.

M Saleh Kasim (1981: 10) kolase adalah menggambar dengan teknik tempelan. Gambar yang berbentuk bukanlah gambar jadi yang ditempelkan akan tetapi kulit telur atau bahan lain yang ditempelkan.

Muharam E (1992: 84) menyatakan bahwa kolase adalah tehnik melukis dan mempergunakan warna-warna kepingan batu, kaca, marmer, keramik, kayu, yang ditempelkan. Kolase merupakan bentuk gambar yang diwujudkan dengan menyusun kepingan warna merupakan bentuk gambar yang diwujudkan dengan menyusun kepingan warna yang diolesi lem kemudian ditempelkan pada bidang gambar.

Budiono, MA (2005: mengartikan kolase sebagai artistit yang dibuat dari bahan yang ditempelkan pada permukaan gambar. Sunaryo A (2002: 8-9) menyatakan ketrampilan kolase merupakan aktivitas yang penting dan kompleks. Berbagai unsur rupa yang berbeda karakternya dipadukan dalam suatu komposisi untuk mengekspresikan gagasan artistic atau makna tertentu.

Susanto M. (2002:63), bahwa kata kolase dalam bahasa ingris disebut "collage" dalam bahasa Perancis yang berarti merekat. Selanjutnya kolase dipahami sebagai suatu tehnik seni menempel berbagai macam materi selain cat,seperti kertas, kain, kaca, logam, kulit telur, daun kering dan lain sebagainya kemudian dikombinasi dengan penggunaan cat (minyak) atau teknik lainnya.

Berdasarkan pengertian di atas jika dihubungkan dengan penelitian ini maka kolase adalah tehnik menempel kulit telur dan lain seperti daun kering dan sebagainya yang sudah diwarnai dan ditempelkan di atas kertas karton yang sudah diberi gambar, tujuan dari teknik ini adalah untuk melatih ketrampilan motorik halus anak tuna grahita supaya bisa menggerakkan jari - jari tangannya dengan benar.

Berdasarkan pengamatan di kelompok B TK Pusaka Indah dalam kegiatan motorik halus, ditemukan bahwa hasil belajar anak kurang efektif, diantaranya anak sering mengeluh kecapaian saat diberi tugas, anak suka bermalas malasan, kurang memperhatikan contoh, sehingga hasil kurang maksimal. 
Jurnal Warna : Jurnal Pendidikan Dan Pembelajaran Anak Usia dini. September 2018. Vol 03. No. 02

Oleh karena itu dalam proposal akan dibahas tentang kegiatan kolase yang juga sering membuat anak kurang bersemangat. Selain itu guru juga mengalami kesulitan terutama dalam pemilihan bahan yang dirasa paling tepat dan efektif, oleh karena itu dalam penelitian ini akan digunakan daun kering sebagai bahan tempelan, sehingga kegiatan kolase menjadi kegiatan yang kreatif, menarik dan menyenangkan.

Berdasarkan uraian tersebut di atas, peneliti berupaya mengadakan perbaikan dalam kegiatan kolase dengan mengambil judul : Peningkatan Keterampilan Motorik Halus Anak Dengan Kegiatan Kolase bahan daun kering di Kelompok B TK Pusaka Indah Samarinda Tahun Ajaran 2016/ 2017.

\section{METODE PENELITIAN}

\section{Desain Penelitian}

Penelitian yang digunakan dalam penelitian ini adalah Penelitian Tindakan

Kelas (PTK). Menurut Arikunto, dkk (2006:57), penelitian tindakan kelas yaitu penelitian yang dilakukan oleh guru, bekerjasama dengan .peneliti (atau dilakukan oleh guru sendiri yang juga bertindak sebagai peneliti) di kelas atau di sekolah tempat ia mengajar dengan penekanan pada penyempurnaan atau peningkatan proses dan praktis pembelajaran. Pendekatan yang akan digunakan dalam penelitian ini adalah pendekatan Penelitian Tindakan Kelas (PTK).
Tujuan dari penelitian tindakan kelas adalah memperbaiki proses pembelajaran nyata yang terjadi di kelas, meningkatkan kegiatan guru dalam pengembangan kompetensi propesional, dan memperbaiki berbagai persoalan nyata yang terjadi dalam meningkatkan mutu pembelajaran, sehingga tujuan dari pembelajaran dapat tercapai dengan baik. Penelitian tindakan kelas dilakukan oleh guru sendirisebagai peneliti di kelasnya, atau berkolaborasi dengan guru kelas dengan cara merancang, melaksanakan, merefleksi tindakan secara partisipasif dengan tujuan meningkatkan mutu pembelajarn tertentu dalam suatu siklus pembelajaran. Oleh karena itu dalam hal penelitian ini yang di utamakan adalah meningkatkan kualitas pembelajaran dengan media yang dianggap tepat untuk meningkatkan keterampilan motorik halus anak dengan kegitan kolase bahan daun kering.

\section{Subyek Penelitian}

Subyek penelitian ini adalah guru dan anak didik kelompok B TK Pusaka Indah Samarinda, yang berjumlah 20 orang anak terdiri dari 12 orang anak laki- laki, dan 8 orang anak perempuan. Obyek dalam penelitian ini adalah peningkatan keterampilan motorik halus anak dengan kegiatan kolase pada anak kelompok B TK Pusaka Indah. 
Jurnal Warna : Jurnal Pendidikan Dan Pembelajaran Anak Usia dini. September 2018. Vol 03. No. 02

\section{Prosedur Penelitian}

Prosedur penelitian adalah langkahlangkah operasional baik yang terkait dengan perencanaan, pelaksanaan, observasi dan refleksi. Dalam perencanaan ini guru dan peneliti secara kolaboratif merencanakan tindakan. Langkah- langkah prosedur penelitian meliputi :

1. Perencanaan yang meliputi

a. Permohonan ijin kepada Kepala Sekolah dan guru kelompok B sebagai mitra peneliti.

b. Mengadakan penelitian awal untuk memperoleh data

c. Memperkenalkan metode pembelajaran dengan metode pemberian tugas anak TK.

d. Menyusun rencana pembelajaran yaitu menyusun RKM dan RKH.

e. Menyiapkan media yang diperlukan selama proses pembelajaran dan penelitian berlangsung

f. Penilaian hasil kegiatan anak setelah proses pembelajaran dan penelitian berlangsung.

g. Menyiapkan instrumen pengumpul data untuk digunakan dalam pelaksanaan tindakan.

\section{Pelaksanaan Tindakan}

Pada tahap pelaksanaan tindakan dilakukan secara kolaboratif antara peneliti dengan guru kelompok B melaksanakan kegiatan melatih motorik halus anak, pada saat kegiatan pembelajaran sedang berlangsung yaitu pada kegiatan inti.

\section{Observasi}

Mengamati secara langsung objek yang diteliti dan secara langsung melaksanakan metode tersebut dan mengamati tingkah laku anak didik dalam proses kegiatan mengisi pola.

\section{Refleksi}

Hasil yang diperoleh dari observasi akan diteliti agar dapat mengetahui kegiatan kolase dapat meningkatkan perkembangan motorik halus anak. Dalam penelitian ini penulis rencananya akan menggunakan dua siklus.

\section{Siklus Pertama}

Pada siklus pertama diawali dengan perencanaan dan langkah- langkah kegiatan pembelajaran dengan menyiapkan RKM dan RKH sebelum kegiatan pembelajaran berlangsung. Siklus pertama dilaksanakan dalam satu minggu dengan satu tema pembelajaran selama dua kali pertemuan selanjutnya melaksanakan evaluasi apakah kegiatan kolase dapat meningkatkan motorik halus anak dengan melihat rata-rata perkembangan motorik halus anak didalam kelas dengan mencapai $80 \%-100 \%$ dari jumlah anak di dalam kelas. Apabila belum tercapai maka dilaksanakan lagi tahap siklus II.

2. Siklus Kedua

Siklus kedua, tahapan perencanaan sama dengan siklus pertama yaitu menyiapkan RKM dan RKH. Siklus kedua dilaksanakan dalam satu minggu dengan 2 kali pertemuan 
masih dalam tema yang sama namun sub tema dan indicator (tiperan) yang berbeda. Selanjutnya melaksanakan evaluasi dari kegiatan tersebut, apakah kegiatan mengisi pola dapat meningkatkan perkembangan motorik halus anak, dengan melihat ratarata perkembangan anak didalam kelas dengan mencapai $80 \%-100 \%$ dari jumlah anak di dalam kelas. Apabila belum tercapai maka tidak akan dilanjutkan karena penelitian dilaksanakan 2 siklus.

\section{Teknik Pengumpulan Data}

Teknik pengumpulan data yang rencananya akan dilakukan berupa

\section{Observasi}

Merupakan suatu pengamatan yang dilakukan dengan teliti dan sistematis untuk tujuan tertentu, atau suatu teknik yang dilakukan dengan cara mengadakan pengamatan secara teliti serta pencatatan secara sistematis (Suharsimi Arikunto,(2006:156) .

2. Dokumentasi

Dokumentasi berasal dari kata dokumen yang artinya barang-barang tertulis. Dalam pengertian yang lebih luas dokumen bukan hanya berwujud tulisan saja, tetapi dapat berupa bendabenda peninggalan seperti prasasti dan simbol-simbol. (Arikunto, 2006:158)

\section{Teknik Analisis Data}

Untuk menentukan kelebihan dan kelemahan tindakan, data yang diperoleh akan dianalisis dengan mean (rata-rata). Pelaksanaan pembelajaran pengembangan motorik halus melalui kegiatan kolase dikatakan berhasil jika, kegiatan pembelajaran minimal mencapai $75 \%$ 100\% yang berarti BS (baik sekali) dari jumlah siswa yang ada dikelas.

$\mathrm{X}=\frac{\sum X}{N} \times 100 \%$

Keterangan

$\mathrm{X}=$ Nilai Rata- rata

$\sum \mathrm{X}=$ JumlahSemuaNilai

$\mathrm{N} \quad=$ JumlahMurid

(SuharsimiArikunto, 2009:264)

Untuk mengetahui keberhasilan dalam penelitian peningkatan motorik halus anak, dilakukan dengan membuat perbandingan skor sebelum dan sesudah kegiatan kolase dengan menggunakan berbagai macam media dan diantaranya adalah dengan daun kering. Dan penelitian ini dianggap berhasil apabila anak dapat merobek, menjimpit dan menempel dengan baik sesuai arahan guru .

\section{HASIL PENELITIAN}

Pertemuan pertama pada siklus I dilaksanakan pada hari senin 15 Mei 2017. Pelaksanaan penelitian Peningkatan Keterampilan Motorik Halus Anak Dengan Kegiatan Kolase Di Kelompok B TK Pusaka Indah Samarinda Tahun Ajaran 2017-2018 dilaksanakan dalam 2 siklus. Dan masing- masing siklus dilaksanakan dalam 2 kali pertemuan. Adapun penelitian 
Jurnal Warna : Jurnal Pendidikan Dan Pembelajaran Anak Usia dini. September 2018. Vol 03. No. 02

dilaksanakan sesuai dengan perencanaan seperti yang sudah diuraikan dalam Bab III, yang tentunya dalam setiap pembelajaran mengacu pada RKH dan RKM yang sudah disiapkan yaitu guru sebagai peneliti melaksanakan kegiatan sesuai dengan indikator yang sudah dipersipakan serta mencatat setiap hasil yang diamatinya,dengan langkah- langkah sebagai berikut :

1. Pertemuan pertama diawali dengan baris, do'a bersama dan salam serta Tanya jawab dan menyanyi atau bersyair sesuai tema, setelah itu dilanjutkan dengan kegiatan inti yaitu kolase pada gambar kemeja dengan proses sebagai berikut. Guru menyiapkan pola gambar serta alat yang digunakan sesuai jumlah anak kemudian guru memberikan contoh cara merobek daun mangga, menggoles lem, menempel dan cara menjimpit.

2. Seperti pada pertemuan pertama, pertemuan kedua juga diawali dengan baris berbaris, berdo'a, salam dan menyanyi sesuai tema, kemudian dilanjutkan dengan kegiatan inti yaitu kolase dengan daun mangga kering padaa gambar celana panjang. Pada pertemuan kedua ini anak sudah mulai menunjukkan ketertarikannya pada kegiatan kolase sehingga hasilnya lebih meningkat dan hasil pada siklus I dapat dilihat pada tabel berikut ini. yang benar, setelah itu guru mempersilakan anak mulai mengerjakan tugas kolase.

Dari hasil kegiatan kolase pada gambar kemeja dan celana dengan media daun mangga pada siklus I dapat diketahui bahwa keterampilan merobek daun ada 6 anak atau 30\% anak sudah mencapai hasil berkembang sangat baik ( BSB), 14 anak atau $70 \%$ anak sudah menunjukkan hasil berkembang sesuai harapan ( $\mathrm{BSH})$. Pada ketepatan menempel ada 7 anak atau 35\% mencapai hasil berkembang sangat baik ( BSB), 10 anak atau 50\% berkembang sesuai harapan ( $\mathrm{BSH}$ ) dan 3 anak atau 15\% pada tahap mulai berkembang (MB). Sedagkan pada keterampilan menjimpit terdapat anak 6 anak atau 30\% pada tahap berkembang sangat baik ( BSB), 11 anak atau 55\% pada tahap berkembang sesuai harapan ( BSH ) dan 3 anak atau 15\% pada tahap mulai berkembang ( MB). Berdasarkan hasil pada siklus I maka dapat dikatakan bahwa keterampilan kolase anak sudah mulai berkembang dibandingakan pada saat kondisi awal atau sebelum tindakan.hal ini disebabkan anak sudah mulai tertarik dan pola gambar yang berbeda pada tiap kegiatannya. Hal ini dapat dilihat pada tabel rata-rata berikut ini 


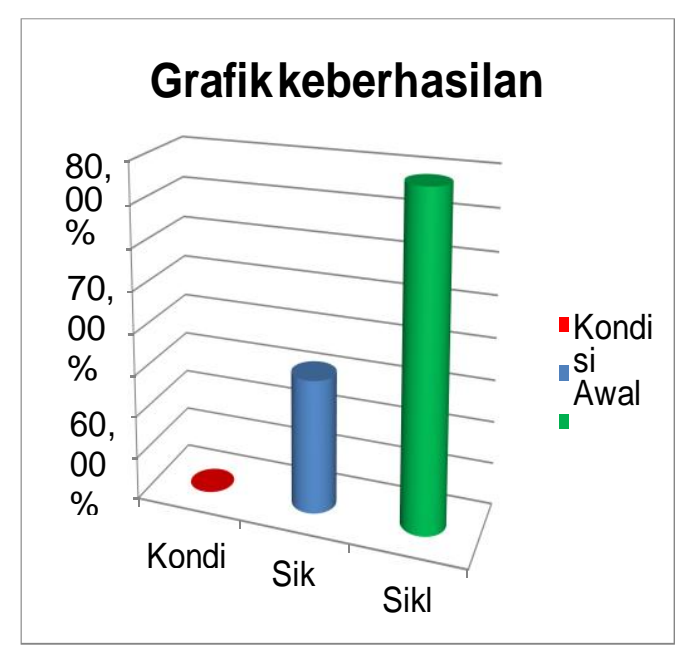

Grafik 1. Grafik Keberhasilan Belajar anak antara kondisi awal, siklus 1 dan 2

\section{PEMBAHASAN}

Keterampilan motorik halus adalah keterampilan yang menitik beratkan pada koordinasi antara otot- otot kecil pada jari tangan, pergelangan tangan yang tidak terlalu membutuhkan tenaga, namun sangat membutuhkan kecermatan, Semakin baiknya gerakan motorik halus anak membuat anak dapat berkreasi, seperti menggunting kertas, menggambar, mewarnai, serta menganyam. Namun tidak semua anak memiliki kematangan untuk menguasai kemampuan ini pada tahap yang sama, hal ini disebabkan oleh beberapa faktor, diantaranya faktor hereditas atau faktor bawaan sejak lahir, faktor lingkungan dan faktor kecerdasan anak serta aktivitas anak sebagai subyek yang bebas berkemauan,punya emosi dan usaha untuk membangun diri sendiri. Berdasarkan hasil penelitian yang dilaksanakan pada anak didik kelompok B TK Pusaka Indah
Samarinda, dalam upaya peningkatan keterampilan motorik halus anak dengan kegiatan kolase, guru sebagai penelitimenemukan beberapa kendala, diantaranya anak masih mengalami kesulitan saat menempelkan bahan pada pola gambar dan tidak suka saat mengambil lem dengan tangan. Pada kondisi awal penelitian persentase keberhasilannya $0,00 \%$ dan tergolong sangat kurang, dari hasil yang dicapai belum sesuai kriteria karena dalam kriteria disebutkan bahwa penelitian dikatakan berhasil apabila anak memperoleh nilai sangat baik dengan persentase lebih dari $80 \%$, hal ini disebabkan pada kondisi awal anak masih kesulitan merobek daun sehingga robekan masih besar- besar dan menjimpit karena jari anak- anak lengket dengan lem, serta alat yang dipersiapkan guru kurang lengkap. Hal itu juga dapat dilihat dari hasil observsi keterampilan motorik halus anak sebelum tindakan diketahui terdapat Untuk meningkatkan hasil belajar sesuai dengan kekurangan pada siklus I maka guru sebagai peneliti melakukan perbaikan pada siklus I. Beberapa tindakan perbaikan yang akan dilaksanakan adalah memberi contoh bagaimana cara merobek dun yang benar, menambah alat ( cutton bud) sehingga tangan anak tidak lengket lagi dengan lem.

Setelah melakukan tindakan pada siklus I sehingga pelaksaanan pada siklus II menjadi meningkat. Pada siklus I setelah dilakukan tindakan dengan dua kali 
pertemuan maka hasil persentase ketuntasan belajar anak adalah $31,7 \%$.

Hasil yang meningkat tersebut dapat dilihat dari robekan daun anak- anak sudah relativ kecil dan anak - anak sudah tidak kesulitan menempel dan menjimpit karena tangan sudah tidak lengket dengan lem. Namun jika didasarkan pada kriteria nilai, hasilnya masih juga belum sesuai karena belum $80 \%$ anak memperoleh nilai sangat baik, sehingga penelitian dilanjutkan pada siklus II. Untuk memperoleh hasil yang maksimal pada siklus II ada beberapa hal yang dipersiapkan oleh guru sebagai peneliti, yaitu bahan tempelannya lebih bervariasi. Pada. Pada siklus II nilai masing- masing aspek telah sesuai dengan kriteria nilai sangat baik yaitu nilai persentase ketuntasan belajar anak sebesar $78,33 \%$. Dengan demikian nilai pada siklus II telah memenuhi kriteria yang diharapkan. Hal ini disebabkan anak sudah semakin senang dengan kegiatan ini dan hasil karya anak- anak sudah semakin rapi, disamping itu bahan yang dipersiapkan juga mempengaruhi hasil karya anak.

Kesimpulan dari siklus II menunjukkan bahwa kegitan kolase dapat meningkatkan keterampilan motorik halus anak. Sesuai dengan tujuan perkembangan motorik halus adalah penguasaan keterampilan yang tergambar dalam kemampuan menyelesaikan tugas motorik halus tertentu. Kualiatas motorik terlihat dari seberapa jauh anak tersebut mampu menampilkan tugas motorik yang diberikan dengan tingkat keberhasilan tertentu, jika tingkat keberhasilan dalam melaksanakan tugas tinggi berarti motorik yang dilakukan efektif dan efisien. (Yudaha M. Saputra 2005: 114)

Pada penelitian ini, guru sebagai peneliti tetap mengedepankan konsep pembelajaran bermain sambil belajar, belajar seraya bermain dimana anak terlibat langsung dalam kegiatan pembelajaran yang telah dirancang oleh guru, oleh karena itu seorang guru TK harus lebih kreatif dalam memberikan pembelajaran dan tentunya tetap memperhatikan prinsip dan aspek- aspek perkembangan anak usia TK, serta harus dapat menyajikan kegiatan yang menarik dan menyenangkan sehingga tujuan dari pembelajaran dapat tercapai dengan baik.

\section{PENUTUP}

\section{Kesimpulan}

Perbaikan dan penyempurnaan kegiatan kolase akan bermanfaat dalam usaha meningkatkan keterampilan motorik halus anak, karena hal ini diperlukan sebagai landasan bagi tahap perkembangan selanjutnya dalam upaya meningkatkan sumber daya manusia dimasa yang akan datang, dimana salah satu aspek yang menjadi tujuan pendidikan adalah berkembangnya keterampilan motorik halus anak yang akhirnya dapat berpengaruh terhadap perkembangan- perkembangan 
yang lainnya.

Keterampilan motorik halus anak setelah dilakukan dengan kegiatan kolase yang telah dirancang guru sebagai peneliti mengalami peningkatan yang bertahap setiap siklusnya. Pada kondisi awal, berdasarkan lembar observasi hasil ratarata ketuntasan belajar anak adalah $0 \%$ dan pada siklus I hasil aktifitas anak meningkat menjadi $31,7 \%$, dan pada siklus II meningkat menjadi $75 \%$ dengan kategori baik.. Berdasarkan pada penelitian tindakan kelas yang dilakukan pada anak didik kelompok B1 TK Pusaka Indah Samarinda, maka dapat di simpulkan bahwa dengan kegiatan kolase keterampilan motorik halus anak dapat ditingkatkan.

\section{Saran}

Rekomendasi dan saran diberikan kepada

1. Anak Didik : Bagi peserta didik hendaknya lebih sering lagi melakukan latihan- latihan agar keterampilan motorik halusnya lebih dapat berkembang dengan baik sesuai tahapan perkembangannya.

2. Guru diharapkan memperhatikan dan mempersiapkan semua bahan sebelum mengadakan kegiatan sehingga saat berlangsung kegiatan guru bisa lebih memperhatiakan anak didik, sehingga hasilnya dapat maksimal, selain daripada itu guru harus bersabar dalam membimbing anak karena anak mempunyai tingkat perkembangan yang berbeda - beda.

3. Bagi sekolah hendaknya mensosialisaikan kepada guru lain bahwa kegiatan kolase bisa meningkatkan keterampilan motorik halus anak.

\section{DAFTAR PUSTAKA}

Bambang, Sujiono dkk. 2005. Metode Pengembangan Fisik. Jakarta : Universitas Terbuka

Basuki Wibawa. 2004. Penelitian Tindakan Kelas. Jakarta : Departemen Pendidikan Nasional Direktorat Jenderal Pendidikan Dasar dan Menengah Direktorat Tenaga Kependidikan

Depdiknas 2006, Pedoman Penilaian PAUD. Jakarta Departemen Pendidikan Nasional Direktorat Jenderal Pendidikan Dasar Dan Menengah

Dewi, Rosmala. 2005. Berbagi Masalah Anak TK. Jakarta, Departemen Pendidikan Nasional Direktorat Jenderal Pendidikan Tinggi Direktorat Pemibanaan Pendidikan Tenaga Kependidikan Dan Ketenagaan Perguruan Tinggi.

Direktur Pembinaan TK dan SD 2007. Pedoman Pembelajaran Bidang Pengembangan Seni di Taman Kanak-kanak. Jakarta: Departemen Pendidikan Nasional.

Kartini, Kartono. 2007. Psikologi Anak (Psikologi Perkembangan). Bandung: Mandar Maju

M. Saleh Kasim. 1981. Kerajinan Tangan. Jakarta. Depdiknas 
Jurnal Warna : Jurnal Pendidikan Dan Pembelajaran Anak Usia dini. September 2018. Vol 03. No. 02

Muharram. E.1993. Pendidikan Kesenian II (Seni rupa). Jakarta: Depdikbud Saputra M, Yudha dan

Rudyanto. 2005. Pembelajaran Kooperatif Untuk Meningkatkan Keterampilan Anak TK. Jakarta Departemen Pendidikan Nasional Direktorat Jenderal Pendidikan Tinggi Direktorat Pembinaan Pendidikan Tenaga Kependidikan Dan Ketenagaan Perguruan Tinggi.

Suharsimi, Arikunto, Suhardjono, Supardi, 2006. Penelitian Tindakan Kelas. Jakarta: Rineka Cipta

Sumantri. 2005. Model Pengembangan Ketrampilan Motorik Anak Usia Dini. Jakarta: Departemen Pendidikan Nasional Direktorat Jenderal Pendidikan Tinggi Direktorat Pembinaan Pendidikan Tenaga Kependidikan Dan Ketenagaan Perguruan Tinggi

Yuliani Nurani, Sujiono. 2009. Konsep Dasar Pendidikan Anak Usia Dini. Jakarta: Indeks Zainal Aqib, 2009. Penelitian Tindakan Kelas. Bandung : Yrama Widya 